\title{
A Structure Analysis for Ecological Management of Moist Tropical Forests
}

\author{
Adrien Djomo Njepang \\ Department of Geography, Queen's University, Kingston, ON, Canada K7L 3N6 \\ Correspondence should be addressed to Adrien Djomo Njepang; djomoa@queensu.ca
}

Received 27 September 2014; Accepted 16 January 2015

Academic Editor: K. S. Rao

Copyright (C) 2015 Adrien Djomo Njepang. This is an open access article distributed under the Creative Commons Attribution License, which permits unrestricted use, distribution, and reproduction in any medium, provided the original work is properly cited.

Human interventions alter stand structure, species composition, and regeneration capacity of the forest. There is no enough information on how different management systems affect the forest structure. The main objective of this study was to analyze the differences on stand structure and species composition caused by different logging intensities. The study was conducted in a lowland evergreen moist forest of 22000 ha in Cameroon. The forest was subdivided into three forest types with different human impacts: 2-Logged, 1-Logged, and Unlogged. The diameter corresponding to mean basal area of stems of 2-Logged $(31.8 \mathrm{~cm}, N=369)$ was almost equal to that of Unlogged $(30.1 \mathrm{~cm}, N=496)$. 1-Logged had a lower diameter of $27.7 \mathrm{~cm}, N=530$. In the three forest types, the diameter distribution followed the inverse J-shaped curve frequently observed in natural forests. The stand basal area increased from $29.4 \mathrm{~m}^{2} /$ ha in 2-Logged, to $32 \mathrm{~m}^{2} /$ ha in 1-Logged, and to $35.3 \mathrm{~m}^{2} /$ ha in Unlogged. These results indicated that logging affected natural regeneration in 2 -Logged. Above $60 \mathrm{~cm} \mathrm{dbh}$, the logging effect was not visible. On 103 tree species found in the sample forest, only nine were classified as harvestable commercial species.

\section{Introduction}

With increasing climate change on the Earth, reducing emissions from deforestation and forest degradation (REDD+) has gained momentum as a climate mitigation strategy [1]. In the tropics, large amounts of carbon are stored in biomass and soils of forests ecosystems [2]. Deforestation and forest degradation of tropical forests cause the emission of the carbon stored in the outgoing vegetation into the atmosphere through burning of slashed wood or gradual decay [3]. During the period between 1980 and 1190, tropical deforestation accounted for at least a quarter of all anthropogenic carbon emissions [4-6] and it represents currently about $20 \%$ of the total greenhouse gas emissions [1, 7]. Between 1990 and 2005, tropical deforestation progressed at an average rate of 11.3 million ha per year due to settlements or to abandonment of agricultural or forest use [3].

In Cameroon, over 18 million hectares of historic forests which are defined as forest cover prior to large-scale human disturbance have been cleared to make way for agriculture and human settlements. Most of this clearing occurred in the central part of the country within moist deciduous forests and savannah woodlands. Nearly 2 million hectares of forest were lost between 1980 and 1995 [8]. According to FAO [9], the forest cover changed from 26076000 ha in 1990 to 23858000 ha in 2000 , representing an annual loss of $222000 \mathrm{ha}$, and a deforestation rate per year of $0.90 \%$. In the Congo Basin, the average deforestation rate per year in the period $1980-1995$ was $0.60 \%$ [8]. This value decreases to $0.13 \%$ per year during the period $1990-2000$ and increases to $0.26 \%$ per year during the period 2000-2005 [8, 10]. In Cameroon, the deforestation rate per year moved from $0.10 \%$ during the period $1990-2000$ to $0.17 \%$ during the period $2000-2005$ with a net deforestation rate per year of $0.03 \%$ in the same period [10-12]. The annual deforestation rate reported by FAO [13] contrasted with these values. According to FAO [13] the forest lost per year was on average 220000 ha which moved at a rate of $0.94 \%$ during the period $1990-2000,1.02 \%$ during the period $2000-2005$ and $1.07 \%$ during the period $2005-$ 2010. Ernst et al. [14] explained that the difference between 
the two estimates may be due to the methodologies used for assessment.

Deforestation and forest degradation cause changes to soil physical, chemical, and biological properties that reduce site productivity [17]. These activities modify stand structure, species composition, and forest density which results from a change on microclimate, ground vegetation, and nutrient cycle [18]. The modifications caused by deforestation and forest degradation are abrupt and often drastic [19] and need assessment to evaluate their impact on the stand structure and species composition.

A survey in the study area aided with the map, the local population, and the information provided from forest administration allowed the subdivision of the municipal forest Yokadouma into three forest types with different human impacts, 2-Logged, 1-Logged, and Unlogged. The respective forests were compared to each other with regard to species composition and stand structure. The following questions prevailed: (1) what are the species composition and stand structure in the different forest types? (2) Has logging affected the biodiversity in logged forests? The main objective of this research was to analyze the structure, the diversity, and also the impact of harvest on the municipal forest Yokadouma under different logging intensities. The specific objectives of this study were (i) to analyze the species composition and stand structure of the different forest types, (ii) to analyze the impact of harvesting on the forest structure, and (iii) to compare the different forest types and explore their potential in species with commercial value.

\section{Material and Methods}

2.1. Study Site. Cameroon is a country of $475000 \mathrm{~km}^{2}$, divided in 10 regions. The research area was situated in the eastern province of Cameroon, within the district of Boumba and Ngoko, in the subdistrict of Yokadouma. Yokadouma, the closest city of the study area, is in the heart of tropical moist deciduous forest; it is located at $650 \mathrm{~km}$ from Yaoundé, the political capital, and $900 \mathrm{~km}$ from Douala, the economic capital. This area has the most productive forest of the country. More than $50 \%$ of the forest concessions which have been already allocated are concentrated in the eastern province. Approximately the lower two thirds of the eastern province are covered with moist forests, which grow progressively as one travels south and east. The forests are composed of evergreen hardwood species. There are many species of secondary uses and several nontimber forest products (NTFP). Some of the species grow up to heights of 50 meters or more. There are also numerous ferns and orchids $[10,12,20]$.

The forest research area has a surface of 22000 ha and belongs to the municipality of Yokadouma. It is located between the latitude $3^{\circ} 17^{\prime} 33^{\prime \prime} \mathrm{N}$ and $3^{\circ} 25^{\prime} 9^{\prime \prime} \mathrm{N}$ and the longitude $14^{\circ} 44^{\prime} 22^{\prime \prime} \mathrm{E}$ and $14^{\circ} 53^{\prime} 33^{\prime \prime} \mathrm{E}$. The geological formations in this area are of Precambrian origin, comprised of sandstones rich in quartz, schists, and limestones. Ferralitic acid soils of red and red-brown color with high clay content and a surface horizon characterized by a low activity of organic matters are dominant in this region; in some areas, the ferralitic soils are interwoven with hydromorphic soils of brown-black color which are rich in organic matters [20]. The topography is in general gently undulating with valleys and ridges among flat basins, ranging in elevation from 400 to $700 \mathrm{~m}$ above sea level [21]. The climate is equatorial of Guinean type, with four distinguished seasons constituted of two rainy seasons and two dry seasons. The climate has a classical feature distributed generally in four periods: from mid-March to mid-June, there is a shorter and less intensive rainy season; from mid-June to mid-August, there is a short dry season; from mid-August to mid-November, there is a long and heavy rainy season; from mid-November to mid-March, there is a long dry season. The mean temperature fluctuates between $23^{\circ} \mathrm{C}$ and $25^{\circ} \mathrm{C}$ with very low variation during the year. The annual rainfall varies between $1600 \mathrm{~mm}$ and $2000 \mathrm{~mm}$ [22]. The data used for construction of this figure were obtained at the "Direction Meteo Douala Cameroun" on the observed period 1982-1993. The river system in the municipal forest Yokadouma is very dense and belongs to the Congo Basin. The most important rivers are the Boumba and its affluents, the Landjoue, and the Mouapack rivers.

2.2. Data Collection. The study area was subdivided into three forest types with different human impacts. The three forests types were 2-Logged, 1-Logged, and Unlogged (Figure 1). 2-Logged was the part of forest where logging activities were carried out two times in the past. 1-Logged was the part of forest where logging activities were carried out once in the past. Unlogged was the part of forest where no reported logging activity took place in the past.

Many silvicultural parameters use one hectare as a reference unit [23]. Consequently, in each stratum, 10 sample plots of $1000 \mathrm{~m}^{2}$ each, representing a total of one hectare, were selected in the transect line on each forest type. The plots of rectangular shape of $20 \mathrm{~m} \times 50 \mathrm{~m}$ each were located on transects, at interval of $500 \mathrm{~m}$ between plots (Figure 2). Subplots denoted by B in Figure 2, of $20 \mathrm{~m} \times 5 \mathrm{~m}$, were used for seedling assessment in each plot. All trees with $\mathrm{dbh}$ exceeding $20 \mathrm{~cm}$ were recorded in the $20 \mathrm{~m} \times 50 \mathrm{~m}$ plot. In the subplot, recruits with dbh ranging between 10 and $19 \mathrm{~cm}$ were recorded additionally. Young trees with dbh less than $10 \mathrm{~cm}$ were not assessed to follow the rule of data collection for forest management in Cameroon which do not take into account this diameter range. In total, 30 plots representing an area of 3 ha were used for this study. For each tree, the species name, the dbh, the class of quality, the stratum, and their exact location on the field with $x$ and $y$ coordinates were assessed.

\subsection{Data Analysis}

2.3.1. Species Classification. Tree species were classified based on their current and future potential commercial value and also based on their size [24]. Four group species were used for classification: $I$ : mature merchantable species, with diameter above the minimum felling diameter (MFD), II: immature merchantable species, with diameter under the minimum 


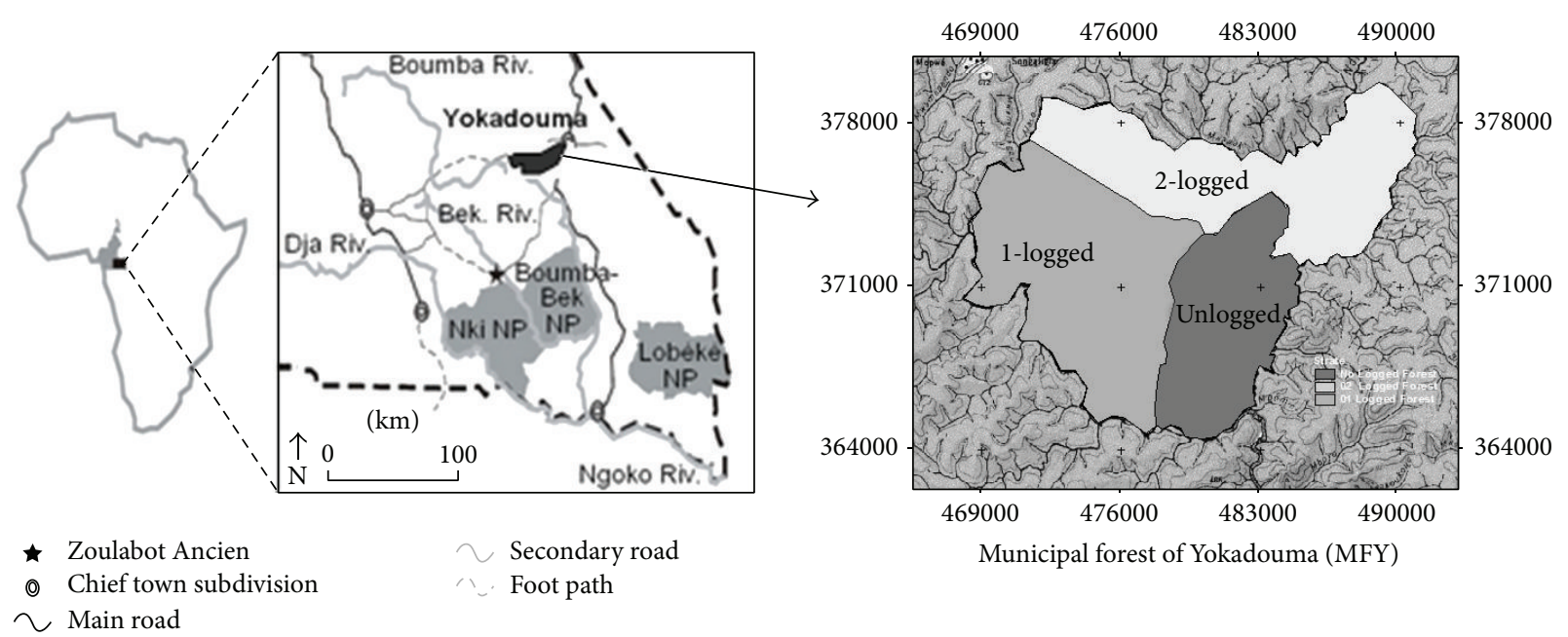

FIGURE 1: View of Cameroon in Africa; location of the municipal forest Yokadouma (MFY) (black shaded) and the forest reserves Boumba Bek, Nki, and Lobeke (gray shaded) (source: adapted fromYasuoka, 2006 [15]).

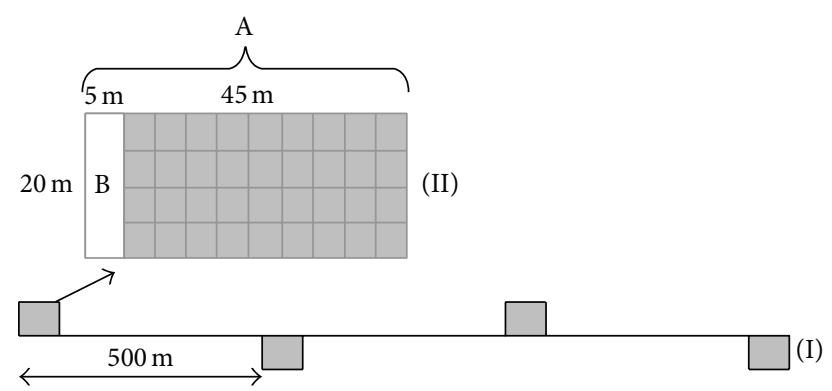

FIGURE 2: Representation of a sample plot with rectangular form of dimension $20 \mathrm{~m} \times 50 \mathrm{~m}$ (A). All trees above $20 \mathrm{~cm}$ dbh were recorded in the entire plot $\mathrm{A}(20 \mathrm{~m} \times 50 \mathrm{~m})$. In the subplot $\mathrm{B}(20 \mathrm{~m} \times$ $5 \mathrm{~m}$ ), the seedlings were recorded additionally.

felling diameter, III: other trees species with MFD assigned by forest administration, and $I V$ : all other tree species (or without assign $M F D$ ).

2.3.2. Analysis of Forest Structure. A forest stand can be characterized by the mean diameter, diameter distribution, stand height, stand density, basal area, stand volume, and other quantitative pieces of information collected from forest inventories [23]. In the tropics, the target parameter for many forest inventories for timber exploitation is diameter of tree species $[2,20]$. This type of data usually provide basic information for analysis of diameter structure, diameter distribution, mean diameter, or dominant diameter of the forest stand. For characterizing the forest structure, we analyzed the mean diameter, the diameter distribution, the basal area, the floristic composition, and the diversity.

Diameter, Number of Stems, and Basal Area. For this study, the arithmetic mean diameter, the quadratic mean diameter, the diameter of tree corresponding to mean basal area of the stand, and the dominant diameter were used and compared to each other. Number of stems and basal area were used to measure the density of forest stands.

2.3.3. Floristic Composition. Different authors [20, 23, 25] considered the minimum representative area to have been reached when the increase in number of species per unit area remains below $10 \%$ when the sample plot area increases by $10 \%$. The species-area curve of 2-Logged, 1-Logged, and Unlogged was plotted to assess the representativeness of the sample plots based on this hypothesis. Therefore, tree species were counted in an accumulative manner until no more new species appeared. The sampling error results from the fact that only a part of the entire population is assessed. The standard error of the mean basal area in this scope is the most suitable tool to measure the accuracy of the vegetation assessment. Sample size is sufficient when the standard error does not exceed the desired value. For most vegetation assessment, a standard error of $10 \%$ is tolerable $[23,26]$.

To determine and evaluate the ecological importance of species in a given forest stand, the Importance Value Index (IVI) has been used [2]. This index was used to rank the species and the families in each forest type.

2.3.4. Species Diversity. The determination of diversity in biological samples and forest communities can be done using different indices. Since their introduction in the 1960s, many indices have been developed to assess species diversity [27]. The most commonly used diversity indices can be grouped in system of diversity numbers developed by Hill [28] that includes species richness, the Simpson index, and a derivation of the Shannon-Wiener index [27]. For this study, we used Simpson index, Shannon-Wiener index, Evenness, and the complexity index to analyze the species diversity. Throughout this paper, Shannon-Wiener index will be used as Shannon index.

Simpson Index. The index according to Simpson [29] gives the probability of any two individuals drawn at random 
from an infinitely large community [23]. Simpson index was estimated by the following equation:

$$
D=\frac{\sum_{i=1}^{k} n_{i} \cdot\left(n_{i}-1\right)}{N \cdot(N-1)}
$$

where $n_{i}$ is the number of individuals in the $i$ th species, $k$ the total number of species, and $N$ the total number of individuals from all species in the studied stand. The value of $D$ is between 0 and 1 . As $D$ increases, diversity decreases and Simpson index was therefore expressed as 1-D [23].

Shannon Index. An appropriate measure of diversity to use for 1-ha plots is Shannon index $\left(H^{\prime}\right)$, which has shown to be more representative of diversity in larger areas [30]. Shannon index is a measure of uncertainty, providing the probability of picking a dominant species at random $[31,32]$. The entropy of a discrete set of probability $p_{1}, \ldots, p_{n}$ is defined as $H=$ $-\sum p_{i} \cdot\left(\log p_{i}\right)$ [33]. The entropy is the amount of information that is lacking and the information that will be gained if the true outcome is known [34]. Shannon index was estimated using the following equation:

$$
H^{\prime}=-\sum_{i=1}^{k} p_{i} \cdot\left(\ln p_{i}\right),
$$

where $p_{i}$ is the probability of random selection of the $i$ th species $\left(n_{i} / N\right), k$ the total number of species, and $\ln$ the natural logarithm. The maximum value of $H^{\prime}$ is the natural logarithm of the number of species $(\ln k)$.

Evenness. Evenness $(E)$ describes the distribution among species, reaching a value of 1 when all species have equal numbers of individuals or turns to 0 when there is a high variation between the species $[32,35]$. According to [27, 36 , it makes sense to consider species richness and species evenness as two independent characteristics. Evenness [37] was estimated with the following equation:

$$
E=\frac{H^{\prime}}{H_{\max }}=\frac{H^{\prime}}{\ln k},
$$

where $H^{\prime}$ is the observed diversity according to Shannon, $H_{\text {max }}$ the maximum possible diversity, and $k$ the total number of species.

Stand Complexity. McElhinny et al. [38] defined stand complexity as a mathematical representation of the effects of two or more structural attributes, in a single number or index value. They argue that, for a larger pool of structural attributes, this index could function as a reliable indicator of stand level biodiversity and provide a better means for ranking stands in terms of their potential contribution to biodiversity. For this study, the following formula was used to assess and rank stand complexity:

$$
\mathrm{CI}=10^{-3} \times G \times N \times S,
$$

TABLE 1: Accuracy of vegetation assessment in the three forest types 2 Logged, 1 Logged, and Unlogged. Mean basal area $(\bar{g})$, standard deviation (SD), number of plots $(n)$, and standard error in percentage $s_{\bar{g}}(\%)$. Plot size $1000 \mathrm{~m}^{2}$ each.

\begin{tabular}{lccc}
\hline Stratum & $\bar{g} \pm \mathrm{SD}$ & $n$ & $s_{\bar{g}}(\%)$ \\
\hline 2 Logged & $2.9 \pm 0.8$ & 10 & 9 \\
1 Logged & $3.2 \pm 0.9$ & 10 & 9 \\
Unlogged & $3.5 \pm 1.0$ & 10 & 9 \\
\hline
\end{tabular}

where $G$ is the basal area per hectare, $N$ the number of trees per hectare, and $S$ the number of species per hectare.

Similarity Index. The similarity between forest types was analyzed using Sorensen and Jaccard index using the formula [39]:

$$
S=\frac{2 A}{2 A+B+C}
$$

where $A$ is the number of species common in two forest types, $B$ the number of species present only in forest type $B$, and $C$ the number of species present only in forest type $C$.

The effects of human intervention on forest structure and species diversity were further tested using one-way ANOVA. If the effects were significant, means were further analyzed by post hoc comparisons with a confidence level of $P<0.05$. When there was no effect, the Levene test of homogeneity of variances was further performed.

\section{Results}

3.1. Vegetation Assessment and Error. Table 1 shows the values of mean basal area $\bar{g}$ and standard deviation (SD) in $\mathrm{m}^{2}$ and standard error in percentage $s_{\bar{g}}(\%)$ for this research. In all forest types, the standard error of mean basal area was below $10 \%$, suggesting that the estimation of mean basal area is sufficiently accurate for vegetation assessment.

3.2. Mean Diameter. Table 2 shows the diameter of mean basal area of trees and the dominant diameter (arithmetic mean diameter of all trees above $60 \mathrm{~cm} \mathrm{dbh}$ ) in the three forest types. The diameter of mean basal area of $2-\operatorname{Logged}(31.8 \mathrm{~cm}$, $N=369)$ was almost equal to that of Unlogged forest $(30.1 \mathrm{~cm}$, $N=496)$. The 1-Logged had a lower value of $27.7 \mathrm{~cm}, N=$ 530. These figures were contrasted by the dominant diameter which shows bigger size diameter for Unlogged $(87.9 \pm 8.6 \mathrm{~cm}$, $N=24)$ and 1-Logged $(87.4 \pm 8.2 \mathrm{~cm}, N=25)$ compared to 2-Logged $(84.3 \pm 3.9 \mathrm{~cm}, N=29)$.

3.3. Forest Density. Figure 3 shows the diameter distribution of the three forest types. The inverse J-shaped diameter distribution frequently observed in natural forest can be viewed in these distributions. Table 2 shows the stem number per hectare $(N)$, the basal area per hectare $(G)$, and the corresponding relative values in percentage for the three forest types of the municipal forest Yokadouma. Stand basal area increased from $29.4 \mathrm{~m}^{2} /$ ha with 369 trees per hectare in 
TABLE 2: Stand parameters for three forest types with different logging intensities 2-Logged, 1 Logged, and Unlogged. Number of stems per hectare $(N)$, basal areas in $\mathrm{m}^{2} /$ ha $(G)$, and the corresponding relative stem number $(N)$ and basal area $(G)$ in percentage.

\begin{tabular}{lccccccc}
\hline Stratum & $\begin{array}{c}N \\
\text { per ha }\end{array}$ & $\begin{array}{c}G \\
\left(\mathrm{~m}^{2} / \mathrm{ha}\right)\end{array}$ & $\begin{array}{c}N \\
(\%)\end{array}$ & $\begin{array}{c}G \\
(\%)\end{array}$ & $\begin{array}{c}d g \\
(\mathrm{~cm})\end{array}$ & $\begin{array}{c}d_{d} \\
(\mathrm{~cm})\end{array}$ & $\begin{array}{c}N(>60 \mathrm{~cm} \mathrm{dbh}) \\
\text { per ha }\end{array}$ \\
\hline 2-Logged & 369 & 29.4 & 26.5 & 30.4 & 31.8 & 84.3 & 29 \\
1-Logged & 530 & 31.9 & 38.0 & 33.1 & 27.7 & 87.4 & 25 \\
Unlogged & 496 & 35.3 & 35.6 & 36.5 & 30.1 & 87.9 & 24 \\
\hline
\end{tabular}

* $d g$ : diameter of mean basal area: diameter which corresponds to the arithmetic mean of the basal area at breast height of all trees in a forest type.

${ }^{* *} d_{d}$ : dominant diameter: arithmetic mean diameter of all trees above $60 \mathrm{~cm} \mathrm{dbh}$.
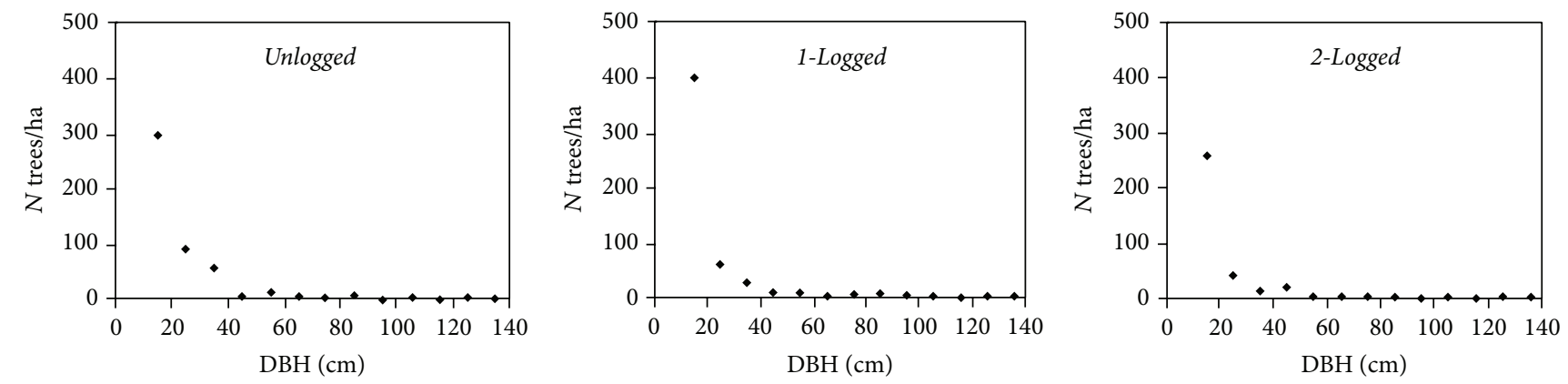

(a)

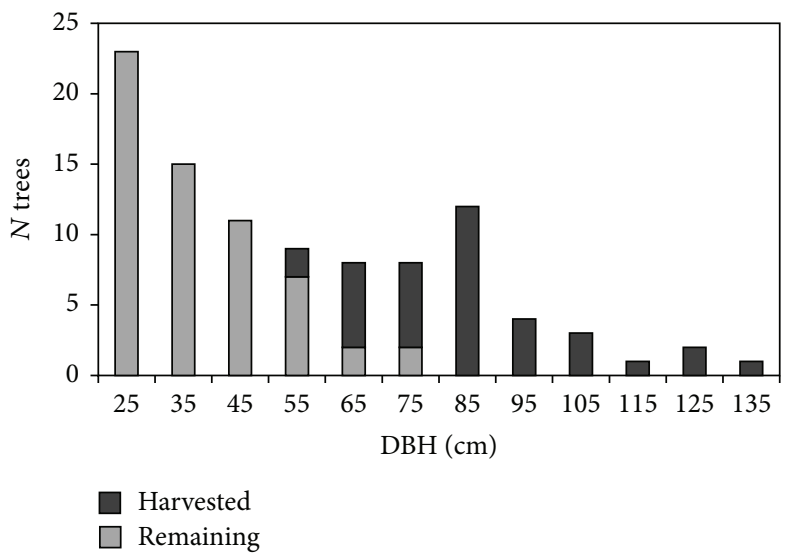

(b)

Figure 3: (a) Diameter distribution of the stem numbers per hectare $(N)$ in the three forests types with different logging intensities. (b) Diameter distribution of commercial species with trees designed for harvest shown with dark shade and the remaining trees after harvest shown with light shade.

2-Logged, to $31.9 \mathrm{~m}^{2} /$ ha with 530 trees per hectare in 1-Logged, and to $35.3 \mathrm{~m}^{2} /$ ha with 496 trees per ha in Unlogged.

Table 3 shows the number of stems per hectare $(N)$, the basal areas per hectare $(G)$, and the corresponding relative value in percentage in the four species groups in the study area. The low basal area in $I\left(7.4 \mathrm{~m}^{2} / \mathrm{ha}\right)$ with 12 trees per hectare indicated that target trees by selective logging with diameter equal or above the minimum felling diameter were constituted by few trees of bigger sizes. The relative high number of stems per hectare (80) with low basal area $\left(3.6 \mathrm{~m}^{2} / \mathrm{ha}\right)$ in $I I$ indicates that there is a good potential of regeneration if unsustainable logging and other human activities such as forest clearance do not hamper this situation. The very high number of trees per hectare in $I I I$ and
IV (372) with basal area $\left(21.2 \mathrm{~m}^{2} / \mathrm{ha}\right)$ indicates that the values of many species are still unknown or not well promoted to forest managers. Table 4 compares the distribution of stem number and basal area in each diameter class for the three forest types.

2-Logged and 1-Logged forests look similar in terms of relative frequency in basal area $(31.0 \%$ and $31.5 \%$, resp.) but are different in relative stem number (25.4\% and $32.2 \%$, resp.). This shows that bigger size trees with less individual may be more in 2-Logged than in 1-Logged. Class I contributes only to $3 \%$ of the stem number but to $23 \%$ of the basal area and Class IV represents $73 \%$ of stem number and $59 \%$ of basal area. Figure 4 shows the distribtion of the basal area in the three forest types (2-Logged, 1-Logged, and Unlogged) based 

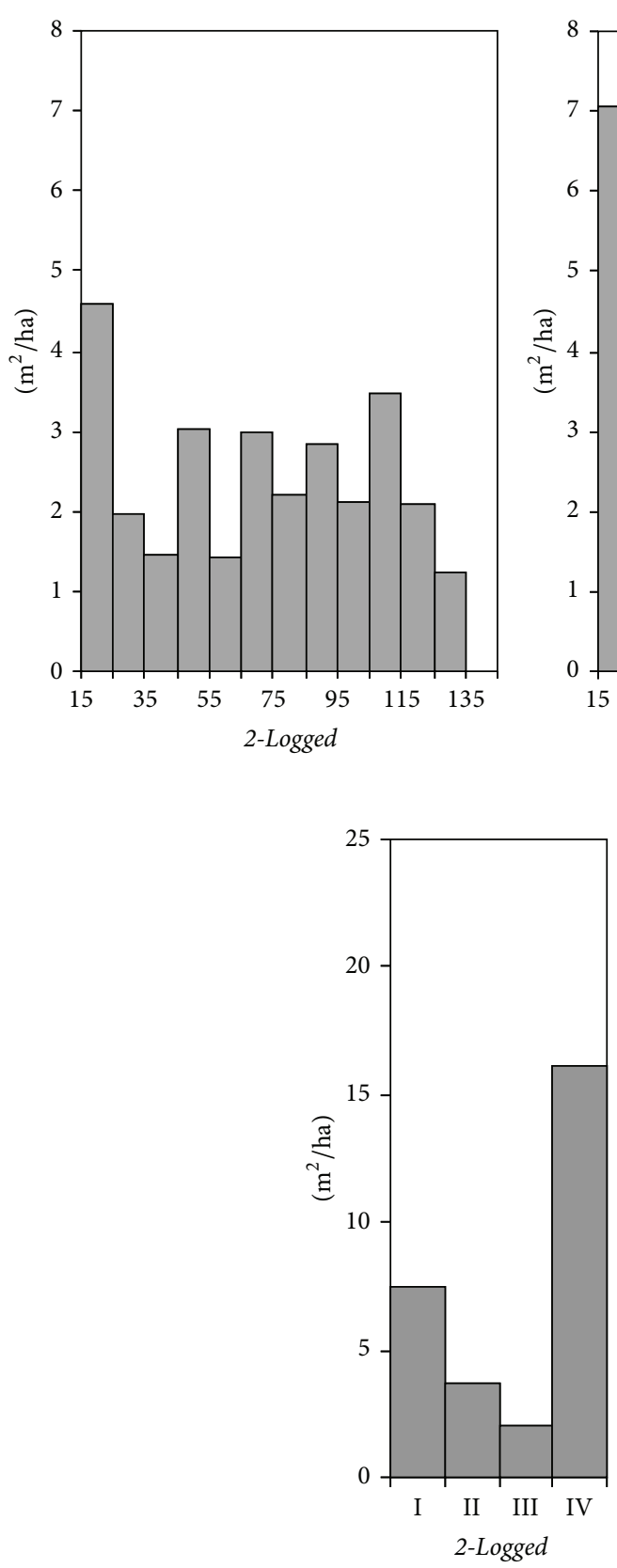
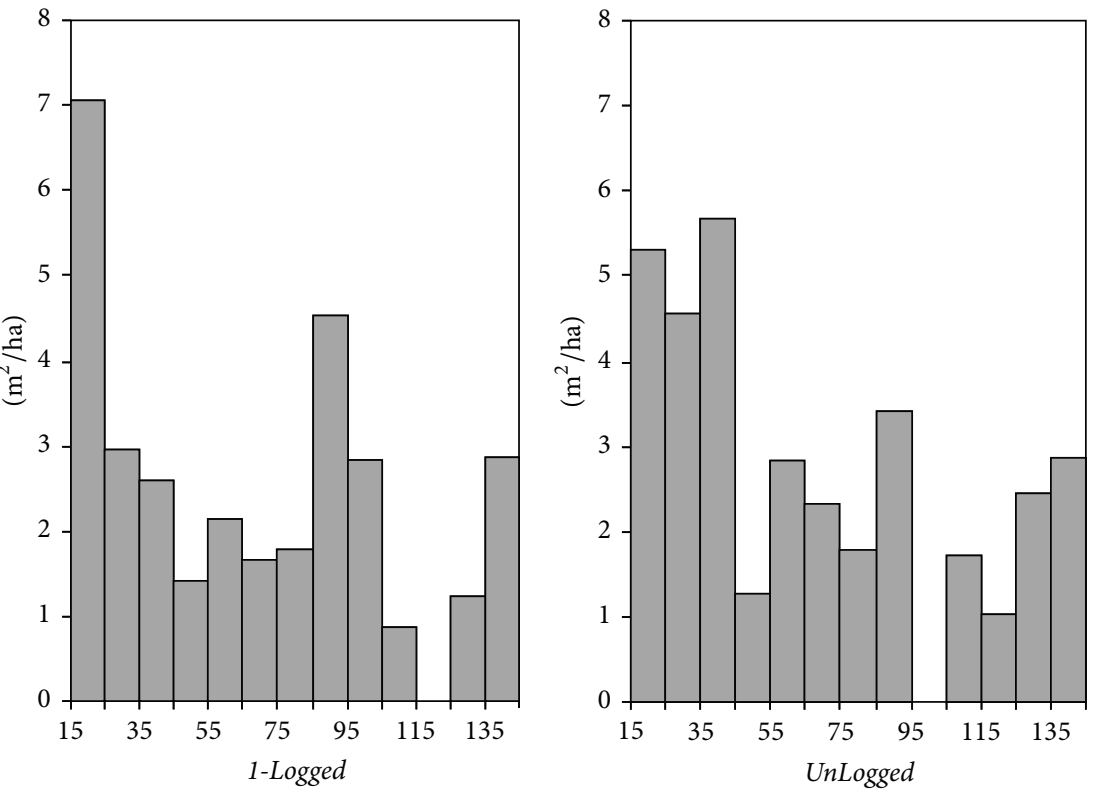

(a)
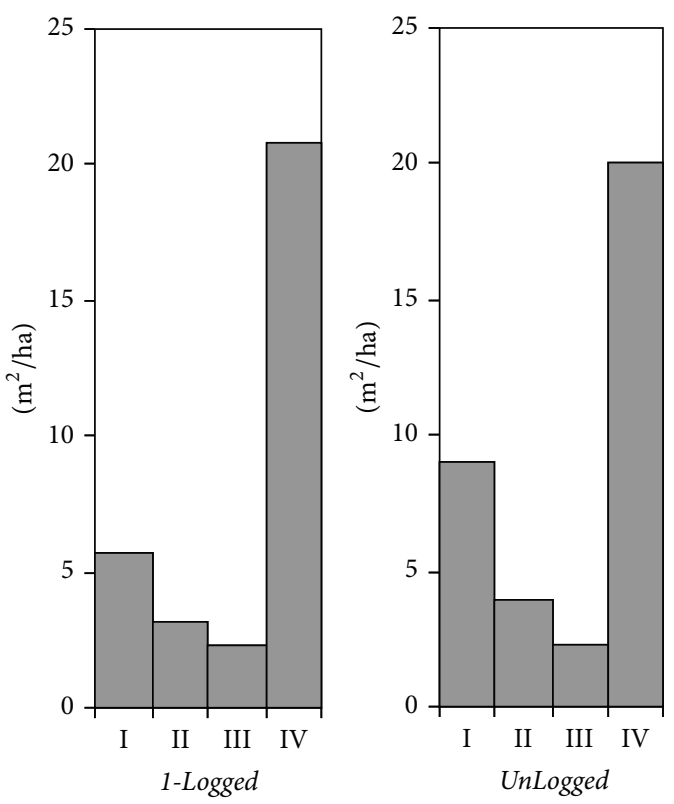

(b)

FIGURE 4: Basal area distribution in the three forest types. (a) Distribution over the diameter classes; (b) distribution over the four species groups (I, II, III, and IV).

on the group species classification $(I, I I, I I I$, and $I V)$ and also based on the diameter class distribution.

One-way ANOVA analysis at $P$-level $<0.05$ showed significant difference in mean diameter in the forest types studied with $P$-level 0.034 . There was no significant difference on basal area among the three forest types. Post hoc analyses performed with least significant difference showed significant difference in mean diameter between 1-Logged and 2-Logged with a $P$-level of 0.025 and a significant difference between
Unlogged and 1-Logged with a $P$-level of 0.30 . There was no significant difference between Unlogged and 2-Logged.

3.4. Floristic Composition. So far, the structure of the stand has been analyzed without considering the floristic composition. The species-area curve of 2-Logged, 1-Logged, and Unlogged was plotted to assess the representativeness of the sample plots. For this purpose, the tree species were counted in a cumulative manner until no more new species appeared. 
TABLE 3: Number of stems per hectare $(N)$, basal areas in $\mathrm{m}^{2} /$ ha $(G)$, and the corresponding relative stem number $(N)$ and basal area $(G)$ in percentage per species group (I: commercial species above MFD, II: commercial species under MFD, III: other species with prescribed MFD, and IV: other species without prescribed MFD).

\begin{tabular}{lcccc}
\hline Groups & $\begin{array}{c}N \\
\text { per ha }\end{array}$ & $\begin{array}{c}G \\
\left(\mathrm{~m}^{2} / \mathrm{ha}\right)\end{array}$ & $\begin{array}{c}N \\
(\%)\end{array}$ & $\begin{array}{c}G \\
(\%)\end{array}$ \\
\hline I & 12 & 7.4 & 2.7 & 23.1 \\
II & 80 & 3.6 & 17.2 & 11.1 \\
III & 31 & 2.2 & 6.7 & 6.9 \\
IV & 341 & 19.0 & 73.4 & 59.0 \\
Total & $\mathbf{4 6 5}$ & $\mathbf{3 2 . 2}$ & $\mathbf{1 0 0}$ & $\mathbf{1 0 0}$ \\
\hline
\end{tabular}

TABLE 4: Stand table representing for each diameter class the number of stems per hectare $(N)$ and basal areas in $\mathrm{m}^{2} / \mathrm{ha}(G)$ for three forest types.

\begin{tabular}{lcccccc}
\hline $\begin{array}{l}\text { DBH } \\
(\mathrm{cm})\end{array}$ & $\begin{array}{c}2 \text { 2-Logged } \\
\text { per ha }\end{array}$ & $\begin{array}{c}G \\
\left(\mathrm{~m}^{2} / \mathrm{ha}\right)\end{array}$ & $\begin{array}{c}\text { 1-Logged } \\
\text { per ha }\end{array}$ & $\begin{array}{c}G \\
\left(\mathrm{~m}^{2} / \mathrm{ha}\right)\end{array}$ & $\begin{array}{c}\text { Unlogged } \\
\text { per ha }\end{array}$ & $\begin{array}{c}G \\
\left(\mathrm{~m}^{2} / \mathrm{ha}\right)\end{array}$ \\
\hline 15 & 260 & 4.6 & 400 & 7.1 & 300 & 5.3 \\
25 & 40 & 2.0 & 60 & 3.0 & 93 & 4.6 \\
35 & 15 & 1.4 & 27 & 2.6 & 59 & 5.7 \\
45 & 19 & 3.0 & 9 & 1.4 & 8 & 1.3 \\
55 & 6 & 1.4 & 9 & 2.1 & 12 & 2.9 \\
65 & 9 & 3.0 & 5 & 1.7 & 7 & 2.3 \\
75 & 5 & 2.2 & 4 & 1.8 & 4 & 1.8 \\
85 & 5 & 2.8 & 8 & 4.5 & 6 & 3.4 \\
95 & 3 & 2.1 & 4 & 2.8 & 0 & 0 \\
105 & 4 & 3.5 & 1 & 0.9 & 2 & 1.7 \\
115 & 2 & 2.1 & 0 & 0 & 1 & 1.0 \\
125 & 1 & 1.2 & 1 & 1.2 & 2 & 2.5 \\
135 & 0 & 0 & 2 & 2.9 & 2 & 2.9 \\
\hline Total & 369 & 29.4 & 530 & 32.0 & 496 & 35.3 \\
\hline
\end{tabular}

In the three forest types, the increase of sample plot area does not increase the species number by more than $10 \%$ above an area of $9000 \mathrm{~m}^{2}$. This suggests that our sample plots can be used for a floral analysis of the forest.

The most common tree species in the forest were ranked based on the Importance Value Index (IVI) [20]. In 2-Logged, the five most common species were Musanga cecropioides R. Brown, Terminalia superba Engl. \& Diels, Triplochiton scleroxylon K. Schum, Klainedoxa gabonensis Pierre ex Engl., and Coelocaryon preussii Warburg.In 1-Logged, the five most common species were Meiocarpidium lepidotum (Oliver) Engl. \& Diels, Terminalia superba Engl. \& Diels, Cordia platythyrsa Baker, Trichilia welwitschii C.DC., and Staudtia kamerunensis Warb. Alstonia boonei De Wild and Mansonia altissima $\mathrm{A}$. Chev. are also present with a relative importance value (sixth and ninth). In Unlogged, the five most common species were Triplochiton scleroxylon K. Schum., Meiocarpidium lepidotum (Oliver) Engl. \& Diels, Corynanthe pachyceras
K. Schum., Mansonia altissima A. Chev., and Ricinodendron heudelotii (Baill.) Pierre ex Pax.

The most common tree families in the three forest types were ranked according to their Importance Index Value [20]. For 2-Logged, the five most common families were Moraceae, Meliaceae, Combretaceae, Euphorbiaceae, andMalvaceae. For 1-Logged, the five most common families were Euphorbiaceae, Meliaceae, Apocynaceae, Annonaceae, andCombretaceae.For Unlogged, the five most common families were Malvaceae, Euphorbiaceae, Moraceae, Meliaceae, and Olacaceae. The tree families Meliaceae and Euphorbiaceae were present in the three forest types significantly with relative high importance for the first one. The species present in the Meliaceae family were Entandrophragma cylindricum Sprague, Trichilia dregeana Swynn. \& Baker f., Trichilia welwitschii C.DC., Guarea cedrata (A. Chev.) Pellegr., Trichilia dregeana Swynn. \& Baker f., and Entandrophragma angolense (Welw.) C.DC. The species present in the Euphorbiaceae family were Meiocarpidium lepidotum (Oliver) Engl. \& Diels, Ricinodendron heudelotii (Baill.) Pierre ex Pax, Uapaca guineensis Muell. Arg., Tetrorchidium didymostemon (Baill.) Pax \& K.Hoffm., Drypetes preussii (Pax) Hutch., Mareyopsis longifolia (Pax) Pax \& K.Hoffm., and Drypetes gossweileri S. Moore. Combretaceae, Moraceae, and Malvaceaewere present in two forest types. The species dominating in Combretaceae was Terminalia superba Engl. \& Diels. In the Moraceae family, the species found at varying importance were Neosloetiopsis kamerunensis Engl., Ficus exasperata Vahl., Bosqueia angolensis (Welw.) Ficalho, Myrianthus arboreus P. Beauv., and Milicia excelsa (Welw.) C.C. Berg. The Apocynaceae and Annonaceae families were only significantly present in 1-Logged and the Olacaceaefamily was only present in Unlogged. The tree species found in the Apocynaceae family were Tabernaemontana crassa Benth., Alstonia boonei De Wild, and Funtumia elastica (Preuss) Stapf. The tree species found in the Annonaceaefamily were Pachipodanthium staudtii Engl. \& Diels, Polyalthia suaveolens Engl. \& Diels, Monodora tenuifolia (Benth.) W. Ash, Enantia chlorantha Oliv., Anonidium mannii (Oliv.) Engl. \& Diels, Xylopia staudtii Engl. \& Diels, and Hexalobus chrispiflorus A. Rich. The tree species found in the Olacaceae family were Strombosia pustulata Oliv., Strombosia grandifolia Hook. f. ex Benth., Strombosiopsis tetrandra Engl., and Olax subscorpioidea Oliv.

For 2-Logged, the 10 most important species carried an index of 131 (corresponding to a proportion of 43\%) while the rest constituted by 55 species carried only 169 . In the same forest the 5 most important species carried an index of 84 (corresponding to a proportion of $28 \%$ ), while the rest constituted by 60 species carried 216. For 1-Logged, the 10 most important species carried an index of 140 (corresponding to a proportion of $47 \%$ ), while the rest constituted by 69 species carried only 160; the 5 most important species carried an index 96. For Unlogged, the 10 most important species carried an index of 115 (corresponding to a proportion of $38 \%$ ), while the rest constituted by 69 species carried 185. For 2-Logged, the 5 most important families carried an index of 124 (corresponding to a proportion of 41\%), while the rest constituted by 22 families carried only 176 . 
TABle 5: Simpson, Shannon, Evenness, and Complexity (CI) index of the three forest types.

\begin{tabular}{lcccccc}
\hline $\begin{array}{l}\text { Forest } \\
\text { type }\end{array}$ & $\begin{array}{c}N \\
\text { per ha }\end{array}$ & $\begin{array}{c}\text { Species } \\
\text { per ha }\end{array}$ & $\begin{array}{c}\text { Simpson } \\
\text { Index } \\
(1-D)\end{array}$ & $\begin{array}{c}\text { Shannon } \\
\text { Index } \\
\left(H^{\prime}\right)\end{array}$ & $\begin{array}{c}\text { Evenness } \\
(E)\end{array}$ & CI \\
\hline 2-Logged & 369 & 59 & 0.96 & 3.48 & 0.85 & 640 \\
1-Logged & 530 & 65 & 0.91 & 3.20 & 0.77 & 1102 \\
Unlogged & 496 & 79 & 0.96 & 3.77 & 0.86 & 1383 \\
\hline
\end{tabular}

For 1-Logged, the 5 most important families carried an index of 144 (corresponding to a proportion of 48\%) while the rest constituted by 25 families carried only 156 . For Unlogged, the 5 most important families carried an index of 151 (corresponding to a proportion of 50\%), while the rest constituted by 28 families carried only 149 .

3.5. Species Diversity. According to Simpson and Shannon index, there was a high degree of diversity in the three forest types with Unlogged the most diversified followed by 2-Logged and then by 1-Logged (Table 5). The same pattern was observed in the distribution of the three forest types according to Evenness index. Stand complexity showed a different pattern. According to this index, Unlogged was the most diversified followed by 1-Logged and 2-Logged; the index value of 2-Logged was almost half of the one of Unlogged which had a value close to that of 1-Logged.

At $P<0.05$, one-way ANOVA analysis and Levene test showed no significant effect of the human intervention on the species diversity using Simpson index and Shannon index. Evenness showed significant difference when using Levene test of homogeneity of variances with $P=0.04$, no significant effect with Brown-Forsythe test, and no significant difference with post hoc tests for pairwise comparison. At $P$ level $<0.10$ the least significant difference showed significant difference between Unlogged and 2-Logged with $P=0.093$. The similarity analysis performed showed that Unlogged and 1-Logged were much similar with a similarity index of 0.71 , while it was only 0.66 between 1-Logged and 2-Logged and 0.64 between 2-Logged and Unlogged.

\section{Discussion}

4.1. Forest Structure. The result of this study showed a fast decrease in stem number from small diameter class to higher diameter classes in the three forest types and in the forest stand. In natural forests where natural regeneration takes place over a long period of time, the number of stems decreases from small to high diameters [2, 20, 23, 25]. The number of tree species per ha increased sharply if the individuals with dbhs between 1 and $10 \mathrm{~cm}$ were included. This finding was consistent with the study of Lamprecht [25] which showed in two forest types that the number of stems per hectare decreases from $(1=571 ; 2=742)$ to $(1=182 ; 2=306)$ when the trees are considered from $10 \mathrm{~cm}$ (diameter class $10-20 \mathrm{~cm}$ ) and $20 \mathrm{~cm}$ (diameter class 20-30 cm), respectively. Van Laar and Akça [40] showed that in uneven-aged natural forests, decreasing distributions were observed which is consistent with this study. Lamprecht [25] indicated that stem numbers of 600 per hectare with a minimum dbh of $10 \mathrm{~cm}$ are generally typical of moist evergreen lowland forests. This number is slightly higher compared with the results of this study $(369 \mathrm{~N}$ per ha for 2-Logged, $530 \mathrm{~N}$ per ha for 1-Logged, and $496 \mathrm{~N}$ per ha for Unlogged) which included a minimum dbh of $10 \mathrm{~cm}$. Djomo et al. [2] studied tree density in agro-forest, managed forest, and national park in a moist forest in South western Cameroon. They found for trees with dbh equal or above $10 \mathrm{~cm}$ a range between 216 to 398 stem number per ha using larger plots of $250 \mathrm{~m} \times 20 \mathrm{~m}(0.5 \mathrm{ha})$ in a total of 12 ha which is smaller compared to the result of this study. Tchouto et al. [41] in the similar forest used plots of 0.1 ha in a total area of 14.5 ha and found density of stems varying between 489 and 741 which was consistent with the result of this study. The present study used plots of $50 \mathrm{~m} \times 20 \mathrm{~m}(0.1 \mathrm{ha})$ in a total of 3 ha. Plots dimension and plots distribution may also play a role in the assessment of the biodiversity and tree density within a forest. The inclusion of young trees less than $10 \mathrm{~cm}$ influences greatly the number of individuals per ha. Bockor [42] indicated that 4900 individuals per ha were found in a forest in western part of Venezuela whilst Marmillod [43] found 5587 trees per hectare in the Amazonian forest with diameter between 1 and $10 \mathrm{~cm}$ included. Djomo et al. [2] for diameter between 1 and $10 \mathrm{~cm}$ found density of stems per hectare varying between 2000 and 4600 in agro-forests, 3867 and 5800 in managed forests, and 4400 and 8400 in national park. This result was consistent with the values in moist forest in Venezuela and Amazon. This study did not measure individuals with diameter below $10 \mathrm{~cm}$.

Brodbeck [23] found the basal area between 31.6 and $33.1 \mathrm{~m}^{2} /$ ha for tree with dbh over $10 \mathrm{~cm}$ in three natural forests of Central Sulawesi, Indonesia. Mitlöhner [44] reported basal areas of up to $31.7 \mathrm{~m}^{2} /$ ha from dry deciduous forest of Paraguay with the same dbh above $10 \mathrm{~cm}$. With the basal area of $32.6 \mathrm{~m}^{2} / \mathrm{ha}$, our findings were consistent with the results of these forest stands. The smallest basal area and number of stems in 2-Logged indicate probably that there was a selective logging with unsustainable harvest which created serious damages on smaller trees. In 1-Logged the highest number of trees per hectare is an indicator that logging may have opened the gaps which facilitated the penetration of light and the growth of (pioneer) light demanding tree species. In 2-Logged, the biggest value of arithmetic mean $(24.5 \mathrm{~cm})$ is another indicator of few trees in smaller diameter class which resulted in a low number of stems per hectare. This pattern could also signify that logging took place in 2-Logged some years ago, and now there is a succession of shade baring trees which are progressively colonizing the pioneer light demanding, fast growing species.

In the Knysna forest, in South Africa, Schütz et al. [16] used basal area as a tool for harvest control. As in this study, they classified the forest in four categories: category $I$ is mature trees of commercially valuable species that have reached a minimum threshold diameter; category II is immature trees of commercially valuable species which will reach 


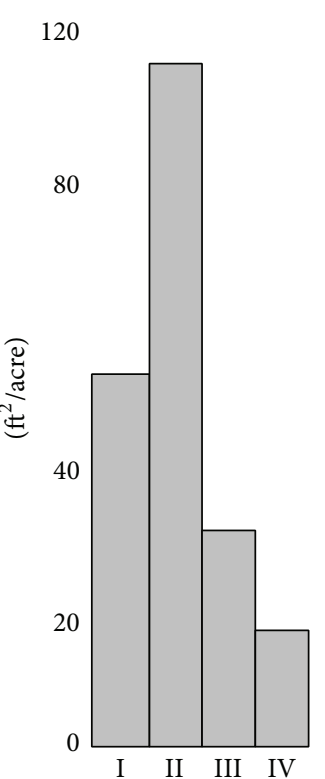

120

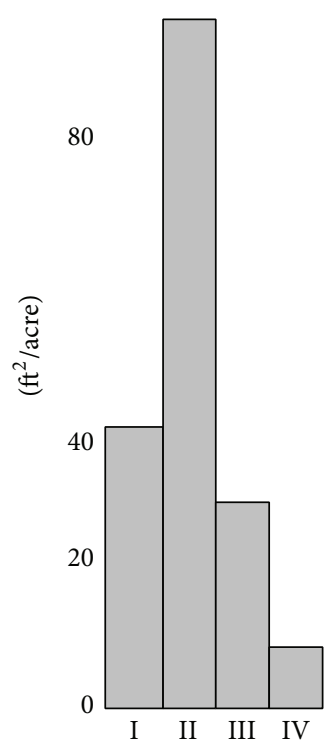

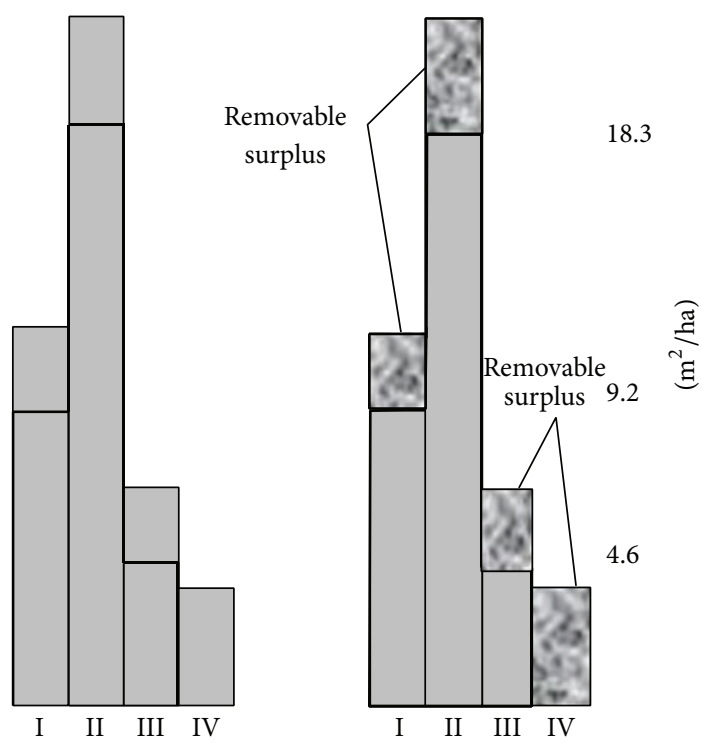

(a)

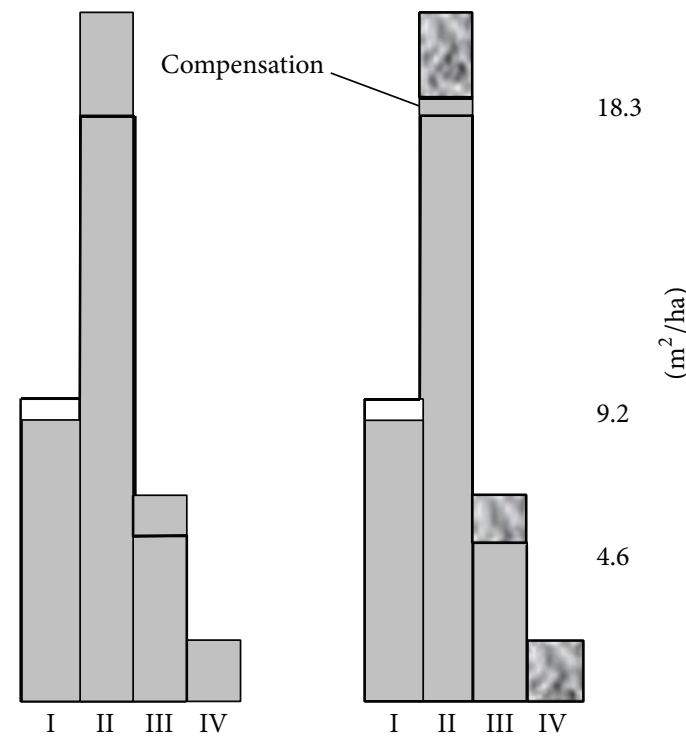

(b)

FIGURE 5: Knysna harvest control method. In each group of species, a threshold is defined. All the trees corresponding to basal area above the threshold will be removed. (a) basal area distribution over tree classes before the harvest, with normal basal area distribution superimposed (centre) and removable surplus (right). (b) The basal area of tree class I is less than the norm. This is compensated by a temporary increase of the norm in class II. The ingrowth into class I will be greater than normal so that the class I basal area will reach normality sooner. The surplus in tree classes III and IV will be harvested [16].

class $I$ when mature; category $I I I$ is other noncommercial tree species; category $I V$ is weed trees and undesirable exotic intruders (Figure 5). In each species class a threshold is defined beyond which all the trees corresponding to basal area above that level will be removed. As in Knysna forest (Figure 5), this study used 4 classes to group species with a similar classification system; Classes I and II had a similar definition, but Classes III and IV had different definition; this resulted in a different shape in basal area distribution among the two studies. Using basal area as harvest control method was not the aim of this study. However, we argue that this management system may have some advantages. In each class, harvest removes the surplus above the threshold. This also gives the possibility to other species which do not have a timber commercial value under the present definition to being harvested in Class III or in Class IV. Also, this 
may also help to easily do the promotion of species without commercial value through the investment in the research in those categories knowing that a harvest quota is assigned in the management system. A management system based only on basal area may have some drawback to monitor the harvest threshold in the field by forest technicians. This study recommends for logging a combination of diameter distribution showing the structure of the forest before and after the harvest as illustrated in Figure 3(b) and basal area control as in Knysna forest for sustainable management of forest.

4.2. Floristic Composition and Species Diversity. Djomo et al. [2] found 145 species with dbh more than $10 \mathrm{~cm}$ in a moist forest in south western part of Cameroon which was consistent with 105 species found in the present studied forest stand. Brodbeck [23] found 81, 89, and 92 species in three natural forests in Central Sulawesi, Indonesia, which was close to the species range of 59,65, and 79 found in 2-Logged, 1-Logged, and Unlogged in the present study. The species composition depicted different physiognomy between the eastern forest (this study) and the western forest [2] which are distant at about $600 \mathrm{~km}$. Though there were some few species similarities between the two forests in terms of species composition, there was no similarity between the 10 most common species. The 5 most important according to IVI index represented on average $29 \%$ in the two eastern and western Cameroonian forests.

According to IVI index, in the three forest types of the present study, on average, only five species of the 10 most important species have known commercial timber value; this shows that there is much effort needed for valorization of species. A research on wood structure, wood property combined with sufficient promotion and valorization, can change the status of noncommercial species to commercial species of very high importance, highly demanded in the market. The ecological value of those species which will not be harvested because of lack of knowledge in their commercial value may play an important role for the carbon sequestration. Knowing that older trees still have to die or may contribute very little to carbon sequestration because of the low growth or growth saturation, valorization may combine ecological and economical functions of the forest. A sustainable harvest needs to be applied to ensure that only trees which have reach the minimum cutting size may be removed from the forest. Harvest analysis is required to ensure that there is sufficient number of small trees in the forest to substitute outgoing trees.

Species diversity takes into account different ecological considerations such as species richness, relative abundance, and evenness [38]. The results of this study followed the same patterns with the study of Brodbeck [23] who analyzed the species diversity in three natural forests in Central Sulawesi, Indonesia, using Simpson index, Shannon index, and Evenness. Simpson and Shannon index followed the same pattern with Evenness. Mulder et al. [35] explained that this could be due to the fact that a greater evenness may be biologically equivalent to having more species.
The complexity index showed a different pattern between the two studies mainly because Brodbeck [23] complexity index integrated the average height in addition to the three parameters associated in this study. When we removed from the study of Brodbeck [23] the average height as interacting parameter and recalculated the complexity factor, our results followed the same pattern except in the 2-Logged showing that the two loggings have seriously affected species diversity within this forest type. McElhinny et al. [38] explained that measuring diversity with indexes such as Shannon, Simpson, or Evenness may quantify only a single attribute and cannot be considered for structural complexity. This study shows that interaction between the attributes may change the perception of species diversity that may be obtained only from indexes mentioned above. Analyzing the complexity on biodiversity structure may integrate as much as attributes such as foliage, canopy cover, diameter, diameter distribution, tree height, tree spacing, tree uniformity, and dead wood. Williams [45] indicated that biodiversity is too broad to measure the entire range of different values or attributes that may affect biodiversity. He suggests refining biodiversity in terms of measurable attributes relevant to the scale and purpose for which it is being assessed which is what was done for this study. Similarity index is another index which may help to better understand the complexity and the difference between distinct forest stands. This index allowed to see that Unlogged and 1-Logged forests were much similar than the other forest types compared pairwise.

\section{Conflict of Interests}

The author declares that there is no conflict of interests regarding the publication of this paper.

\section{Acknowledgments}

This study would not have been possible without the financial support of Deutsche Gesellschaft für Technische Zusammenarbeit (GTZ). The financial assistance of Katholische Hochschulgemeinde (KHG) and International Student Services is greatly acknowledged. The contribution of Professor Dr. Klaus von Gadow in this study is highly acknowledged. The author also acknowledges the contribution of Professor Dr. Zapfack Louis for his review on scientific name of species and families. The author is grateful to the anonymous reviewer whose inputs have helped to improve the content of this paper.

\section{References}

[1] L. Lin, E. Sills, and H. Cheshire, "Targeting areas for Reducing Emissions from Deforestation and forest Degradation (REDD+) projects in Tanzania," Global Environmental Change, vol. 24, no. 1, pp. 277-286, 2014.

[2] A. N. Djomo, A. Knohl, and G. Gravenhorst, "Estimations of total ecosystem carbon pools distribution and carbon biomass current annual increment of a moist tropical forest," Forest Ecology and Management, vol. 261, no. 8, pp. 1448-1459, 2011. 
[3] A. Popp, G. Luderer, K. Vohland, and H. Lotze-Campen, "Mechanisms for avoiding deforestation and forest degradation," in Climate Change, Justice and Sustainability: Linking Climate and Development Policy, O. Edenhofer, J. Wallacher, H. LotzeCampen, M. Reder, B. Knopf, and J. Müller, Eds., pp. 287-295, Springer, Dordrecht, The Netherlands, 2012.

[4] Y. Malhi and J. Grace, "Tropical forests and atmospheric carbon dioxide," Trends in Ecology \& Evolution, vol. 15, no. 8, pp. 332337, 2000.

[5] P. M. Fearnside, "Conservation policy in Brazilian Amazonia: understanding the dilemmas," World Development, vol. 31, no. 5, pp. 757-779, 2003.

[6] R. A. Houghton, "Revised estimates of the annual net flux of carbon to the atmosphere from changes in land use and land management 1850-2000," Tellus, Series B: Chemical and Physical Meteorology, vol. 55, no. 2, pp. 378-390, 2003.

[7] N. Stern, The Stern Review on the Economics of Climate Change, Cambridge University Press, Cambridge, UK, 2007.

[8] H. Bikié, J. G. Collomb, L. Djomo, S. Minnemeyer, R. Ngoufo, and S. Nguiffo, "An overview of logging in Cameroon," Global Forest Watch Cameroon Report, World Resource Institute, 2000.

[9] FAO, "Global forest resources assessment 2000," FAO Forest Paper 140, Food and Agriculture Organization, Rome, Italy, 2001.

[10] R. Nasi, P. Mayaux, D. Devers et al., "Un aperçu des stocks de carbone et leurs variations dans les forêts du bassin du congo," in Les forêts du Bassin du Congo-Etat des Forêts 2008, C. de Wasseige, D. Devers, P. de Marcken, R. Eba’Atyi, R. Nasi, and P. Mayaux, Eds., pp. 199-216, Office des publications de l'Union européenne, Luxembourg, Luxembourg, 2009.

[11] C. de Wasseige, D. Devers, P. de Marcken, R. Eba’aAtyi, R. Nasi, and P. Mayaux, Les Forêts du Bassin du Congo-Etat des Forêts, Office des Publications de l'Union Européenne, 2009.

[12] C. de Wasseige, P. de Marcken, N. Bayol et al., "Les Forêts du Bassin du Congo-état des Forêts 2010," Office des publications de l'Union européenne 1-274, 2012.

[13] FAO, Global Forest Resources Assessment 2010, FAO Forestry Paper 163, FAO, Rome, Italy, 2010.

[14] C. Ernst, A. Verhegghen, P. Mayaux, M. Hansen, and P. Defourny, "Cartographie du couvert forestier et des changements du couvert forestier en afrique centrale," in Les Forêts du Bassin du Congo-État des Forêts 2010, C. de Wasseige, P. de Marcken, N. Bayol et al., Eds., pp. 23-42, Office des Publications de l’Union Européenne, Luxembourg, 2012.

[15] H. Yasuoka, "The sustainability of duiker (Cephalophus spp.) hunting for the baka hunter-gatherers in southeastern Cameroon," African Study Monographs, supplement 33, pp. 95120, 2006.

[16] J.-P. Schütz, T. Pukkala, P. J. Donoso, and K. von Gadow, "Historical emergence and current application of CCF" in Continuous Cover Forestry, T. Pukkala and K. von Gadow, Eds., pp. 1-28, Springer, Amsterdam, The Netherlands, 2nd edition, 2012.

[17] K. T. Osman, Forest Soils: Properties and Management, Springer, 2013.

[18] K. V. Gadow, "Science-based forest design and analysis: philosophy and technology for forest resource management," in Proceedings of the International Symposium on The Role of Forests for Coming Generations, Tochigi, Japan, 2004.
[19] W. Zucchini and K. von Gadow, "Two indices of agreement among foresters selecting trees for thinning," Forest and Landscape Research, vol. 1, pp. 199-206, 1995.

[20] N. A. Djomo, Structure and stand dynamics of a moist evergreen forest in East Cameroon [M.S. thesis], Georg-August-Universität Göttingen, Göttingen, Germany, 2006.

[21] S. J. Gartlan, La Conservation des Ecosystèmes forestiers du Cameroun, IUCN, Gland, Switzeland, 1989.

[22] F. White, "The Vegetation of Africa: A Descriptive Memoir to Accompany the Unesco/AETFAT/UNSCO Vegetation Map of Africa," UNESCO, 1983.

[23] F. Brodbeck, Structure and processes in traditional forest gardens of Central Sulawesi, Indonesia [Ph.D. Dissertation], GeorgAugust-Universität Göttingen, Göttingen, Germany, 2004.

[24] K. von Gadow and J. Puumalainen, "Scenario planning for sustainable forest management," in Sustainable Forest Management, K. von Gadow, T. Pukkala, and M. Tome, Eds., pp. 319-355, Springer, 2000.

[25] H. Lamprecht, Silviculture in the Tropics, Deutsche Gesellschaft für Technische Zusammenarbeit (GTZ), Eschborn, Germany, 1989.

[26] F. Zöhrer, Forstinventur, Parey, Hamburg, Germany, 1980.

[27] C. H. R. Heip, P. M. J. Herman, and K. Soetaert, "Indices of diversity and evenness," Océanis, vol. 24, no. 4, pp. 61-87, 1998.

[28] M. O. Hill, "Diversity and evenness: a unifying notation and its consequences," Ecology, vol. 54, no. 2, pp. 427-432, 1973.

[29] E. H. Simpson, "Measurement of diversity," Nature, vol. 163, no. 4148, p. 688, 1949.

[30] P. Laura, "Biodiversity: inference about richness and shannon index," Interciencia, vol. 31, no. 8, pp. 583-590, 2006.

[31] C. A. Gill and D. N. Joanes, "Bayesian estimation of Shannon's index of diversity," Biometrika, vol. 66, no. 1, pp. 81-85, 1979.

[32] T. C. H. Sunderland, J. A. Comiskey, S. Besong, H. Mboh, J. Fonwebon, and M. Abwe Dione, SI/MAB Series, Vegetation Assessment of Takamanda Forest Reserve, Cameroon, 2003.

[33] C. E. Shannon and W. Weaver, The Mathematical Theory of Communication, The University of Illinois Press, Urbana, Ill, USA, 1949.

[34] K. V. Gadow and B. Bredenkamp, Forest Management, Academica Press, Pretoria, South Africa, 1992.

[35] C. P. H. Mulder, E. Bazeley-White, P. G. Dimitrakopoulos, A. Hector, M. Scherer-Lorenzen, and B. Schmid, "Species evenness and productivity in experimental plant communities," Oikos, vol. 107, no. 1, pp. 50-63, 2004.

[36] C. Heip, "A new index measuring evenness," Journal of the Marine Biological Association of the United Kingdom, vol. 54, no. 3, pp. 555-557, 1974.

[37] E. C. Pielou, An Introduction to Mathematical Ecology, Wiley, New York, NY, USA, 1969.

[38] C. McElhinny, P. Gibbons, C. Brack, and J. Bauhus, "Forest and woodland stand structural complexity: its definition and measurement," Forest Ecology and Management, vol. 218, no. 13, pp. 1-24, 2005.

[39] A. Chao, R. L. Chazdon, and T. J. Shen, "A new statistical approach for assessing similarity of species composition with incidence and abundance data," Ecology Letters, vol. 8, no. 2, pp. 148-159, 2005.

[40] A. Van Laar and A. Akça, Forest Mensuration, Cuvillier, Göttingen, Germany, 1997. 
[41] M. G. P. Tchouto, J. J. F. E. de Wilde, W. F. de Boer, L. J. G. van Der Maesen, and A. M. Cleef, "Bio-indicator species and Central African rain forest refuges in the Campo-Maan area, Cameroon," Systematics and Biodiversity, vol. 7, no. 1, pp. 21-31, 2009.

[42] I. Bockor, Analyse von Baumartenzusammensetzung und Bestandesstrukturen emes andinen Wolkenwaldes in Westvenezuela als Grundlage zur Waldtypengliederung [Ph.D. dissertation], Geog-August-Universität, Göttingen, Germany, 1979.

[43] D. Marmillod, Methodik und Ergebnisse von Untersuchungen über Zusammensetzung und Aufbau eines Terrassenwaldes im peruanischen Amazonien, Georg-August-Universität, Goettingen, Germany, 1982.

[44] R. Mitlöhner, "Die Konkurrenz Der Holzgewächse Im Regengrünen Trochenwald Des Chaco Boreal, Paraguay," Göttinger Beiträge zur Land- und Forswirtschaft in den Tropen und Subtropen, 54, Göttingen, Deutschland, 1990.

[45] J. Williams, "Metrics for assessing the biodiversity values of farming systems and agricultural landscapes," Pacific Conservation Biology, vol. 10, no. 2-3, pp. 145-163, 2004. 

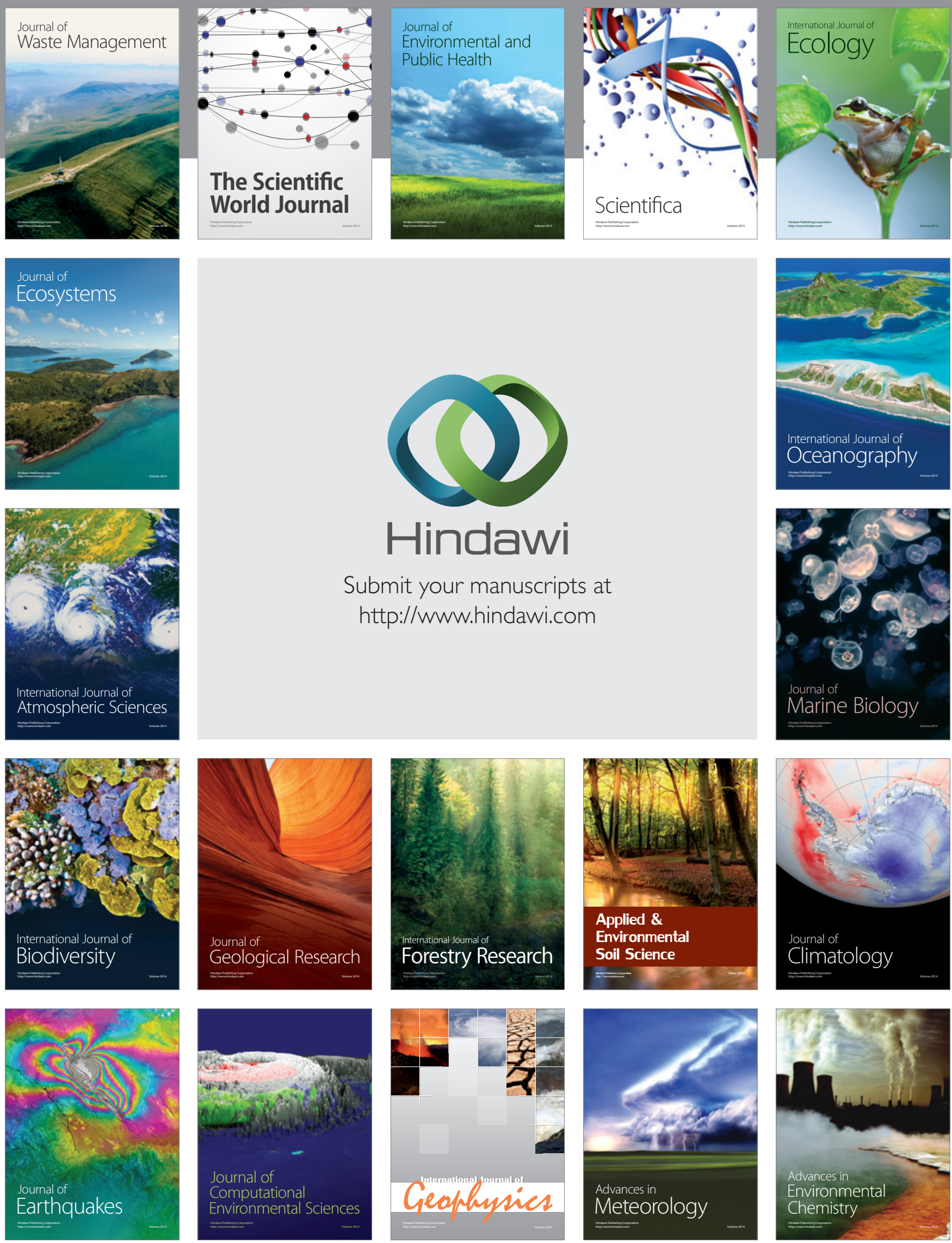